\title{
Religia jako ideologia. Status religioznawstwa i problem transcendencji
}

$\mathrm{D}$ efiniowanie religii należy do najbardziej kontrowersyjnych problemów nauk społecznych w ogóle, a religioznawstwa w szczególności. Jednocześnie kontrowersyjność tę stosunkowo łatwo usunąć - wystarczy się zgodzić, że religijna samoświadomość, jak każda samoświadomość, ma, po pierwsze, skłonność do arbitralnego definiowania samej siebie, i, po drugie, każdy, w tym również człowiek religijny, ma prawo do definiowania samego siebie, i, co więcej, jego autodefinicja powinna być brana pod uwagę, zarazem jednak nie może ona zastępować definicji naukowej, a więc definicji, w ostatecznym rachunku budowanej z zewnętrznego wobec samego obiektu definiowania ${ }^{1}$ punktu widzenia. Tymczasem taki zewnętrzny, naukowy punkt widzenia akurat w religioznawstwie - zwłaszcza w religioznawstwie - nie tylko nie jest uważany za szczególnie wyróżniony, ale jest wręcz traktowany jako jeden z możliwych „poglądów”, podczas gdy religijna definicja religii (jako „drogi do Boga” itp. $\left.{ }^{2}\right)$ jest uważana nie tylko za wyróżnioną, ale nawet za „klasyczną,"3.

1 Szerokie spectrum problemów metodologicznych i teoretycznych związanych z definiowaniem religii omawia Andrzej Bronk w artykule Religia jako pojęcie i przedmiot badań (uwagi metodologiczne), „Przegląd Religioznawczy” 2008, nr 3. Autor nie konceptualizuje kwestii transcendencji, tłumacząc to tym, że pozostaje to „poza możliwościami poznawczymi metod religioznawczych” (s. 14), nie wspomina jednak o możliwościach innych nauk, a tym bardziej o filozofii.

2 Tylora definicja religii jako wiary w duchy (,duchowe byty”), (zob. E. B. Tylor, Primitive Culture, t. 1-2, 1981, t. 1, s. 383 i n.; cyt. za G. Kehrer, Wprowadzenie do socjologii religii, Kraków 1997, s, 28) w zamierzeniu tego uczonego naukowa, może być $\mathrm{w}$ istocie zaliczona do definicji religijnych, pozwala bowiem na korelowanie $z$ religią wszelkiego bytu duchowego i wszelkiej wiary. Tymczasem - przykład pierwszy z brzegu - wiara w dobro nie musi mieć nic wspólnego z religią, chyba że będzie to dobro religijnie definiowane. Religia, powiada samoświadomość religijna ekstrapolowana na definicję, „Jest... związkiem człowieka z Bogiem, który nie jest tworem kultury...”. Z. J. Zdybicka, Religia i religioznawstwo, Lublin 1992, s. 226.

3 Por. artykuł Religia w elektronicznej wersji encyklopedii Religie świata. 
Naturalnie nie dotyczy to religioznawstwa „w ogóle” (religioznawstwo „W ogóle" skłania się raczej do formuły, ujętej w tytule studium Clifforda Geertza, a traktującej religię jako „system kulturowy”4), a tylko religioznawstwa polskiego, i to też nie całego, ale jednak z różnych względów dominującego, religioznawstwa konfesyjnego (badania religioznawcze, zwłaszcza socjologiczne, są najlepiej rozwinięte w uniwersytetach katolickich $^{5}$ ), uprawianego oczywiście z całym sztafażem dyscypliny naukowej.

Oddzielenie religioznawstwa naukowego od religioznawstwa wyznaniowego i kościelnego jest więc konieczne ${ }^{6}$, ale, jak się okazuje, nie jest wystarczające - religia przeniesiona na grunt badań stricte naukowych nie przestaje być problemem, nie przestaje być problemem samo definiowanie religii. Naukowe religioznawstwo i naukowe definiowanie religii, motywowane skądinąd godną pochwały intencją odróżnienia się od religioznawstwa konfesyjnego, gubi coś dla religii istotnego, co powoduje, że konfesyjne religioznawstwo, przy całej jednostronności jego definicji transcendencji, a, w aspekcie politycznym, nawet dzięki tej jednostronności, zachowuje tak wielką żywotność. Wydaje się, że optyka naukowa, często programowo odcinająca się od filozofii jako dyscypliny „nieobiektywnej", pomija to, co w religii (i nie tylko zresztą w religii) jest najważniejsze. Dlatego tak dobrze, przynajmniej na pierwszy rzut oka, brzmi „klasyczna” definicja Zofii Zdybickiej, według której „Religia... jest sposobem istnienia człowieka, sposobem ludzkiej egzystencji, która jest uczestnictwem w istnieniu Boga czy jakkolwiek rozumianej rzeczy-

4 „Religia jest: (1) systemem symboli, które doprowadzają do (2) wytworzenia się u ludzi skutecznych, powszechnych oraz trwałych usposobień i motywacji (3) poprzez formułowanie koncepcji ogólnego porządku egzystencji oraz (4) przybieranie tych koncepcji w taką powłokę realności, iż (5) owe usposobienia i motywacje wydają się wyjątkowo rzeczywiste". C. Geertz, Religia jako system kulturowy, w: Socjologia religii. Antologia tekstów, wybór i wprowadzenie W. Piwowarski, Kraków 2003, s. 42.

5 Liczne polskie uniwersytety mają w swej strukturze wydziały teologiczne, będące w istocie wydziałami teologii katolickiej, a przede wszystkim badania są w nich prowadzone pod ogólną (a w kwestiach światopoglądowych również szczególną) kuratelą akademickich „duszpasterzy”.

6 ,Zagadnienie definicji religii to m.in. problem takiej jej konceptualizacji, by dało się przeprowadzić ostrą granicę między tym co religijne i niereligijne". A. Bronk, Religia jako pojęcie..., op. cit., s. 19. Poniższy tekst stanowi propozycję oddzielenia religii i tego co nią nie jest, jak i oddzielenia religioznawstwa naukowego od konfesyjnego. 
wistości transcendentnej”" . Oczywiście założenie, że istnieje jakiś Bóg (o ile nie uważamy, że jest on tworem ludzkiej wyobraźni ${ }^{8}$, a Zdybicka nie uważa), jest założeniem całkowicie arbitralnym, by nie rzec - ideologicznym, i to już wystarczająco taką definicję dyskwalifikuje, oczywiście $\mathrm{z}$ naukowego, bo nie z konfesyjnego punktu widzenia, ale już nad kwestią ,jakkolwiek rozumianej transcendencji” nie powinno się tak łatwo przechodzić do porządku dziennego jako (w tym wypadku, ale to nie znaczy, że zawsze) synonimem Boga. Wprawdzie definicja Zdybickiej taką synonimiczność zakłada, odnosząc ,jakkolwiek rozumianą transcendencję" do religii, powiedzmy - uznając religię za formę ,jakkolwiek rozumianej transcendencji”, ale to nie oznacza, że jest to jedyne uprawnione jej odniesienie i tym samym jedyne możliwe jej rozumienie. Spróbujmy z pojęciem transcendencji zrobić to, co konfesyjne (ale często i naukowe) religioznawstwo, skądinąd w sposób nieuprawniony, robi $\mathrm{z}$ religią, definiując ją nazbyt szeroko (przypisując religii organizację ,jakkolwiek rozumianej transcendencji”). Spróbujmy pojęcie transcendencji zdefiniować szerzej, niż czyni to teologia. Uznajmy, że pojęcie to oznacza coś więcej (a zapewne też coś innego) niż skłonna jest przyznać religia; uznajmy jednak przede wszystkim, że coś takiego ,jest”. Spróbujmy rozróżnić religijne i nie religijne, powiedzmy: filozoficzne, rozumienie transcendencji. O to w gruncie rzeczy powinien iść spór, zważywszy na to, że również religijne religioznawstwo skłonne jest podzielać formułę Geertza, że religia jest systemem kulturowym. Z tą wszelako różnicą, że „nie tylko”. Trzeba się z religijnym religioznawstwem zgodzić: religia jest systemem kulturowym, ale religia ma również związek $\mathrm{z}$ transcendencją. Albo ściślej: religia, będąc od początku do końca systemem kulturowym, ma związek z transcendencją. Ale tu już zaczynają się różnice fundamentalne. Po pierwsze transcendencja $\mathrm{W}$ rozumieniu religijnym jest tylko częścią transcendencji całej (to postaram się wykazać poniżej), a poza tym - nie tylko religia ma „coś wspólnego” z transcen-

7 Z. J. Zdybicka, Religia i religioznawstwo, op. cit., s. 223-224.

8 Transcendencja jako sfera wyobraźni, ze względu na sposób istnienia tej ostatniej, byłaby logicznie do pomyślenia, ale, po pierwsze, nie byłaby, jako sytuująca się raczej w obrębie estetyki, ekwiwalentem transcendencji w jej rozumieniu religijnym (nad czym można by, ewentualnie, przejść do porządku dziennego), i, po drugie - co znacznie ważniejsze - nie spełniałaby wszystkich dezyderatów metafizycznych: zwłaszcza tych odnoszących się do absolutnego początku i do elementu oraz wytwarzania bytu wyższego. 
dencją. Przy czym to tylko część różnicy: to, co religia nazywa transcendencją nie jest $\mathrm{w}$ istocie transcendencją, a jedynie jej kulturową formą, przy czym jedną z wielu? ${ }^{9}$ Bowiem nie tylko ,religia jest uczestnictwem w transcendencji” albo, mówiąc językiem mniej religijnym, a bardziej filozoficznym, religia jest tylko jedną z form transcendencji. Religia nie ma monopolu na transcendencję, więc i religijne religioznawstwo nie powinno mieć na nią monopolu. Nie powinna mieć na nią monopolu religijna definicja religii.

Zacznijmy od wtrąconego już w powyższy wywód stwierdzenia, że transcendencja ,jest" ${ }^{\prime 10}$. „Jest” umieszczone zostało w cudzysłowie nie dlatego, żeby jakoś zakwestionować czy - tym bardziej - zrelatywizować istnienie transcendencji (jest akurat zupełnie odwrotnie), ale dlatego, by zasygnalizować odmienny od kultury, ale też od natury, sposób jej istnienia. Zresztą również natura różni się sposobem swego istnienia od kultury, co nie jest oczywiście żadnym odkryciem, dosyć szybko bowiem - odkąd stała się kultura przedmiotem zainteresowania nauki, ale także przedmiotem tak zwanej filozofii kultury - różnicę tę uchwycono; chociaż nie brakuje uczonych, tych zwłaszcza, którzy sprowadzają pamięć kulturową do genetycznej, podejmujących zabiegi w odwrotnym kierunku - w kierunku zatarcia różnicy między naturą i kulturą. Tego rodzaju nastawienie ma, nawiasem mówiąc, dostojne antecedencje w „materialistycznym" traktowaniu człowieka jak maszyny, tyle że stworzonej nie przez ludzi, a przez samą naturę. Wydaje się jednak, że przynajmniej od czasu neokantyzmu akcent na różnicę, a więc na rozróżnienie natury i kultury, ma status paradygmatu. Status paradygmatu, w każdym razie w nauce i filozofii, ale już, oczywiście, nie w teologii, ma ograniczenie tego co istnieje, do natury i kultury. Wprawdzie filozofia, ta filozofia, która nie dawała się utożsamić $\mathrm{z}$ nauką ${ }^{11}$, ciagle dotyka tego, co może mieć związek z transcendencją (podkreślmy - nie z transcendencją w ro-

9 Religijnie rozumiana transcendencja jest tylko kulturową formą transcendencji, co nie znaczy, że religia nie pozostaje w związku z transcendencją samą. Czym jest owa „transcendencja sama” (przy założeniu i zastrzeżeniu, że zawsze jest ona zapośredniczona przez formę kulturowa, przez język) i jak ma się do niej religia (włączając $\mathrm{w}$ to jej wyobrażenie transcendencji), o tym między innymi traktuje niniejszy artykuł.

${ }^{10}$ „Tradycyjne” stanowisko ateistyczne zaprzecza istnieniu jakiejkolwiek (jakkolwiek rozumianej) transcendencji. Por.: „Prawdziwy ateizm zakłada odrzucenie wszelkiej transcendencji”. M. Onfray, Traktat ateologiczny, Warszawa 2008, s. 63.

11 Chociaż, paradoksalnie, pragnęła być jednocześnie nauką (Kant), a nawet nauką ścisłą (Husserl). 
zumieniu religijnym) - należy tu w szczególności kwestia wartości - ale skutkuje to albo wyraźnym odcinaniem się od transcendencji jako czegoś trzeciego, obok kultury i natury, i umieszczaniem wartości w kulturze, gdy tymczasem w kulturze są ich kulturowe formy, a nie wartości same (tak postępuje $\mathrm{z}$ nimi socjologia ${ }^{12}$ ), albo przejściem filozofii na pozycje teologii, już to ujętym w języku ściśle religijnym (Bóg itd.), już to w bardziej oględnym, ogólnikowym języku „filozoficznym” („Jedno” itp.). Tu w ostatecznym rachunku leży przyczyna pozostawienia przez filozofię jakiejś szczególnie ważnej kwestii na pastwę pewnego typu ideologii. Musi to budzić zdumienie, zważywszy na to, że sama filozofia powstała jako próba przeciwstawienia się uproszczonemu, mitologiczno-religijnemu objaśnianiu świata, sprowadzającemu rzeczywistość do jednego wymiaru, do jednego z dwóch możliwych rozstrzygnięć metafizycznego dylematu i ukrywającemu sam dylemat (antynomię, sprzeczność itp.) jako immanentną strukturę bytu. Taki dylemat jako pierwszy sformułował już Sokrates (albo Platon z powołaniem się na Sokratesa ${ }^{13}$ ), który zapytywał o relację między bogiem i dobrem, o to, czy bóg jest ponad dobrem, czy dobro jest ponad bogiem. O ile mit nie rozstrzygał jeszcze tej kwestii jednoznacznie (nie była ona w nim zresztą dość precyzyjnie sformułowana), o tyle religia od razu określiła siebie jako ideologię prymatu boga nad dobrem. I tylko wspomniane już ignorowanie samego dylematu pozwoliło religii ukrywać partykularny charakter owego rozstrzygnięcia.

To co wydaje się dziwne z punktu widzenia Platońskiego, i, ogólnie, filozoficznego, sformułowania problemu i zasygnalizowanej tu zasadniczej opozycji między religią i filozofią - mylenie teologizowania z filozofowaniem, przestaje być dziwne, jeśli się spojrzy na zagadnienie w perspektywie historycznej, która ukazuje - począwszy od IV stulecia n.e. - podporządkowanie filozofii (podobnie zresztą jak całej kultury) zinstytucjonalizowanej religii ${ }^{14}$, religii zorganizowanej w Kościół i pań-

12 Socjologiczne i antropologiczne definicje kultury odnotowują istnienie, a nawet szczególne znaczenie wartości dla kultury, ale - może z obawy przed pozornym obiektywizmem ich religijnego rozumienia - sugerują ich rozumienie jako czegoś, co każdy uważa za wartość.

13 Zob. Platon, Eutyfron, w: Platon, Uczta, Eutyfron, Obrona Sokratesa, Kriton, Fedon, Warszawa 1962, s. 195-196. Sokrates, w każdym razie w thumaczeniu Witwickiego, używa słowa „przeciwieństwo”.

14 Najbardziej symptomatyczne (a choćby tylko symboliczne) jest w tym kontekście zamknięcie w roku 529 Akademii Platońskiej. 
stwo. Wprawdzie powstanie uniwersytetów dawało filozofii formalną autonomię, która jednak przez całe stulecia nie mogła się przekształcić w autonomię rzeczywista, a w takich krajach jak Polska nie przekształciła się do dziś ${ }^{15}$. Jednym $z$ dobitnych przykładów tego stanu rzeczy jest ezopowy język takich filozofów jak Ockham, z drugiej - obszerne rozprawianie o Bogu przez Kartezjusza, którego „wynalazek” cogito, a w istocie - „wynalazek” „Ja” jako czegoś, wbrew religii, dysponującego pierwszorzędnym statusem metafizycznym, czyni owo rozprawianie o Bogu metafizycznie zbędnym ${ }^{16}$. Nic dziwnego, że nawiązująca do Kartezjusza filozofia współczesna nawiązuje tylko do ,,cogito” (a więc do „Ja"), pomijając chłodnym milczeniem całe to wielosłowie odnoszące się do Boga. Ma to jednak również negatywne dla filozofii konsekwencje - filozofia wyzwala się od zależności od religii rezygnując ze swojej kompetencji na obszarze zajętym przez religię. To znacząco odróżnia filozofię od nauki, która również potrzebowała wielu stuleci, żeby się wyzwolić spod ideologicznej dominacji religii; odkąd się jednak wyzwoliła, odkąd uczeni się wyzwolili, uprawiają swoje pole nie zwracając na ogół uwagi na to, co mają w kwestii budowy świata do powiedzenia religie, a wiadomo, że do powiedzenia mają wiele i niełatwo rezygnują z narzucania swoich poglądów. Co prawda dotyczy to głównie nauk przyrodniczych, ale i nauki społeczne mają w tym względzie niewiele

15 Autonomię miały te filozoficzne kierunki, które nie wchodziły na obszar zastrzeżony dla „filozofii religijnej”. Autonomię pozorną miał marksizm-leninizm - tylko pozorną, bo miał oczywiście autonomię polityczną, merytorycznie natomiast był tym samym co religia, stał bowiem na stanowisku prymatu swojego „boga”, cokolwiek by nim było, nad dobrem i prawem, oraz „stwórczego” teleologizmu. Marksizm tym się z kolei różni od marksizmu-leninizmu, że nie rozstrzygnął dla siebie do końca tego dylematu.

16 Metafizycznie, ale nie politycznie - uniknął w końcu filozof prześladowań w epoce kontrreformacji, chociaż jego pisma nie uniknęły wpisania do indeksu ksiąg zakazanych. A co do metafizyki: jeśli ,ja” ma pierwszorzędny status metafizyczny, to Bóg albo w ogóle nie dysponuje takim statusem (nie od dziś wiadomo, że status Boga jest symboliczny, a więc, wbrew Zdybickiej, kulturowy), albo ma co najwyżej status metafizyczny równy człowiekowi - przynajmniej dopóki nie wyjaśnimy, czym jest to wszystko, co nie jest ,ja”. Tyle że Bóg, którego status metafizyczny jest równy statusowi metafizycznemu człowieka, do niczego nie jest religii potrzebny, nawet jako symbol - zwłaszcza jako symbol. Uprzedzając dalsze wywody powiedzmy, że już w Starym Testamencie Bóg występuje w roli podmiotu równego metafizycznym statusem człowiekowi. Zresztą jego status jest tam w istocie nie metafizyczny, lecz symboliczny. 
mniejsze poczucie niezależności. Tymczasem w filozofii proporcje są odwrotne - przedmiotem zainteresowania filozofów jest najczęściej epistemologia i jej odgałęzienia, a tylko wyjątkowo to, co zgodnie z narzuconym przez religię przekonaniem jest wyłącznie jej domeną. Nigdy dość podkreślania, że chodzi o filozofię, a nie o teologię występującą w przebraniu filozofii, ta bowiem problemem transcendencji, tyle że religijnie rozumianej, zajmuje się jak najbardziej. Na usprawiedliwienie (oczywiście tylko częściowe usprawiedliwienie) filozofii można dodać, że nauce było łatwiej - religia wprawdzie uporczywie stara się kontrolować obszar, którym interesuje się nauka (stosując zupełnie nienaukowe środki represji), ale ostatecznie nie jest to obszar, na którym religii zależy najbardziej.

Przykładem zastępowania naukowej definicji religii przez ujętą w naukową terminologię jej autodefinicję jest artykuł G. Lanczkowskiego Religia, pomieszczony w encyklopedii Religie świata. Wierzenia, bogowie, święte księgi. Omawiając funkcje religii, autor nie tylko akceptuje bezkrytycznie religijny pogląd o „środku zbawienia" "17 (chociaż trochę się chyba asekuruje ujmując te słowa w cudzysłów), ale uznaje także za stosowne (również za światopoglądem religijnym) stwierdzić, że oprócz tej „swoistej”, religia pełni również funkcje „nieswoiste”, związane z jej „instrumentalnym wykorzystaniem do celów pozareligijnych”. Ta „nieswoistość” przypisywanych religii funkcji (oprócz „zbawczej” jako swoistej właśnie), i konieczność podkreślenia owej nieswoistości jest na tyle ważna, że, chociaż „nieswoiste”, funkcje te są przez Lanczkowskiego drobiazgowo (jak na artykuł w encyklopedii) omówione - chyba właśnie celem szczególnego ugruntowania w świadomości czytelnika przekonania o ich nieswoistości. Autor nazywa niektóre z tych funkcji „instrumentalnymi” sugerując, że właśnie owa instrumentalizacja jest dla religii jak najbardziej „nieswoista”. Taką nieswoistą funkcją religii związaną z jej instrumentalizacją ma być między innymi motywowanie do działania, panowanie nad lękiem, identyfikacja i integracja, ,sankcjonowanie społecznych norm i instytucji” oraz „legitymizacja władzy”

17 Ciekawe z religioznawczego punktu widzenia (jako wyraz zastępowania definicji religioznawczej autodefinicją religijną) jest wyodrębnianie religii „objawionych" (przy czym - bez cudzysłowu), gdy tymczasem bardziej trafne byłoby nazywanie ich religiami, których wyznawcy uważają je za objawione (i wtedy nawet cudzysłów nie byłby potrzebny).

${ }^{18}$ G. Lanczkowski, Religia, w: Religie świata. Encyklopedia PWN. Wierzenia, bogowie, święte księgi, Warszawa 2006, s. 691. 
(to wszystko, co skądinąd przypisuje religii naukowe religioznawstwo $^{19}$ !), czyli funkcja ideologiczna. Czy istotnie funkcja ideologiczna jest nieswoistą funkcją religii? A może obietnica „zbawienia” (nirwany, kontemplacji oblicza Pana, pokonania śmierci itp., itd.) jest tylko swoiście ideologicznym narzędziem realizacji rzekomo nieswoistej ideologicznej funkcji? Podobnie jak obietnica bezbrzeżnej satysfakcji z zakupu reklamowanego towaru? Może religia jest niczym innym, jak tylko totalną (w obu znaczeniach tego terminu) ideologią ${ }^{20}$ ? Twierdząca odpowiedź na to pytanie nie od dziś wydaje się oczywista - na przykład w wersji Marksowskiej, tej o „opium ludu”, czy w wersji Wolterowskiej, fałszywie ubolewającej nad tego ludu niedojrzałością - i nie warto by było wyważać otwartych drzwi ${ }^{21}$, gdyby nie to, że nazbyt często religioznawstwo zastępowane jest przez teologię. A więc spróbujmy jeszcze raz odpowiedzieć na pytanie, czym właściwie jest religia, dorzucając w miarę możliwości kilka dodatkowych argumentów.

Według niej samej (a dokładniej - według religijnych religioznawców) jest ona uniwersalną formą organizacji kultury, łączącą kulturę i jednostkę z transcendencją. Filozoficzny ogląd spowoduje częściową tylko korektę tego przerostu ambicji: religia jest $\mathrm{w}$ istocie jedną $\mathrm{z}$ form organizacji kultury, łączących kulturę i jednostkę $\mathrm{z}$ transcendencją. Ale skoro (albo: ale jeśli) jest religia tylko jedną $\mathrm{z}$ form, pełniących tę funkcję, to i organizacja kultury, i więź z transcendencją, muszą się realizować w jakiś specyficzny (specyficzny właśnie dla religii) sposób, różny od sposobu, właściwego dla innych, pełniących tę funkcję, form. Jakie to są formy? Powiedzmy ogólnie, biorąc zresztą za wzór religię i jej niewatpliwie archetypiczny (i w tym sensie tylko ,uniwersalny”)

19 Wynika z tego niedwuznacznie, że nauka zajmuje się czymś, co właściwie do religii się (jako dla niej „nieswoiste”) nie odnosi, a więc zajmując się religią właściwie się nią nie zajmuje. Pod jednym względem z tak surowym poglądem na temat nauki trzeba by się zgodzić (chociaż dotyczyć to może tylko filozofii, ona bowiem ma instrumenty, z pomocą których może sobie radzić z tym problemem): nauka nie potrafi, bo nie ma po temu środków, a filozofia nie chce, bo zostawia to teologii, odpowiedzieć na pytanie, czego kulturową formą jest religia.

20 Nie dlatego „niczym innym”, by była ideologią w sensie wąskim (doktryna i etos), a w tym, że funkcję ideologiczną pełnią również inne jej elementy, w tym zwłaszcza organizacja i kult. Sama zaś funkcja ideologiczna jest również funkcją organizacyjną.

21 „«Religia» jest ideologicznym, praktycznym i symbolicznym wyznacznikiem...”. D. Hervieu-Leger, Religia jako pamięć, Kraków 1999, s. 119. 
charakter $^{22}$ : to instytucje, które w dostatecznie długim czasie, na dostatecznie dużym obszarze i wśród dostatecznie dużej populacji organizują kulturę. Nietrudno wskazać instytucje spełniające te kryteria, tu jednak interesuje nas przede wszystkim ideologiczna funkcja (albo nawet ideologiczna istota) tylko jednej z nich, religii; zaznaczmy jedynie, że pozostałe pełnią podobne ideologiczne funkcje, chociaż nie wszystkie pełnią je podobnie, co skądinąd decyduje o odmienności typów kultur $^{23}$.

Powyższe rozważania są jedynie wstępem do właściwego wywodu, który ma odpowiedzieć na pytanie, czym jest religia i uargumentować zarazem tezę o jej immanentnie ideologicznym, a nawet ,instrumentalnym" ${ }^{24}$, charakterze. Należy przy tym odnotować, że nie chodzi po prostu o ideologię jako drogowskaz dla działania politycznego, ale o coś więcej - o ideologię jako drogowskaz dla kultury; w wypadku religii o określoną ideologię jako drogowskaz pewnego ty p u kultury. Argumentację tę zaprezentuję poprzez analizę tekstu, uchodzącego - niesłusznie - za tekst par excellence religijny, a nawet „objawiony” - analizę niezwykłej opowieści o stworzeniu człowieka, zawartej w Księdze Rodzaju Starego Testamentu. Niezwykłość tej opowieści polega na tym, że wbrew utartym sądom konfesyjnym nie jest to opowieść religijna („,objawiona" itd.), więcej nawet - wbrew utartym sądom naukowej tym razem biblistyki (i ,antyreligijnej” krytyki) nie jest ona nawet mitologiczna, chociaż, co oczywiste, jest zbudowana $\mathrm{z}$ mitologicznego materiału. Opowieść o stworzeniu człowieka jest konstruktem filozoficznym - złożona jest bowiem, zupełnie jak dylemat Platoński, z przeciwieństw ${ }^{25}$. Zgódźmy się na początek co do tego, że przekaz religijny nie może być antynomiczny; może nie być (i najczęściej nie jest) dosłowny, musi być jednak jednoznaczny. Mówiąc w pewnym uproszczeniu: postępuj tak i tak, a nie: postępuj jak uważasz. Tymczasem przesłanie biblijnej opo-

22 Tak jak pośród religii ,archetypiczny” charakter mają tzw. religie księgi.

23 W sprawie tak zwanych dominant kulturowych (religia jest właśnie jedną z nich, pozostałe to magia, prawo i reklama) zob. W. Paradowska, R. Paradowski, Typology of cultures and economy in culture, „Hemispheres. Studies on Cultures and Societies" 2003, No 18.

24 W cudzysłowie, bo nie w sensie pejoratywnym (jak np. u Lanczkowskiego w związku z ,nieswoistością”), ale w sensie narzędzia transmisji wartości (określonego typu wartości) do kultury.

25 W sprawie „dylematu Platońskiego” zob. R. Paradowski, Platon, idea dobra i filozofia demokracji, „Przegląd Politologiczny” 2010, nr 3. 
wieści o antropogenezie głosi właśnie: postępuj tak jak uważasz ${ }^{26}$. Opowieść biblijna ma formę dylematu.

Fakt ten nie jest nawet jakoś specjalnie zamaskowany w strukturze biblijnej narracji. Antynomiczny charakter biblijnej opowieści o stworzeniu można by wręcz traktować jak niewartą szczególnego uzasadnienia oczywistość, gdyby nie to, że religijna rekonstrukcja tej opowieści ową antynomiczność ignoruje (ignoruje nawet fakt istnienia aż dwóch opowieści, chociaż go bezpośrednio nie neguje $\mathrm{e}^{27}$ ), a mniej lub bardziej religijna biblistyka dostrzega ją (i odnotowuje) jedynie jako ślad o charakterze historycznym ${ }^{28}$ i ,archeologicznym”. Religijna rekonstrukcja i interpretacja (mamy tu bowiem do czynienia właśnie z interpretacją) przekształca antynomiczność biblijnej narracji w pojedynczą opowieść o tym, że (mówiąc w pewnym skrócie) „Bóg stworzył człowieka z prochu ziemi na swój obraz, zabronił mu spożywania owoców z drzewa wiadomości złego i dobrego, a kobietę stworzył z żebra". Właśnie owo przekształcenie antynomii w jednoznaczny przekaz, zbudowany zasadniczo z materiału jednego tylko opowiadania, i to właśnie tego o drzewie i o żebrze, $\mathrm{z}$ niewielkim, choć istotnym zapożyczeniem $\mathrm{z}$ drugiego z nich (pojęcia „obrazu Bożego”) pełni par excellence ideologiczną funkcję; więcej nawet - decyduje o istocie religii jako ideologii.

Tymczasem, jako się rzekło, opowiadania o stworzeniu człowieka są dwa, i to różniące się między sobą zasadniczo. Dwa są zresztą również opowiadania o stworzeniu świata, które także różnią się w sposób zasadniczy. Tego, że są nie tylko dwa opowiadania o stworzeniu człowieka, ale również dwa opowiadania o stworzeniu świata, oficjalna redakcja tekstu specjalnym podtytułem nie odnotowuje. A warto na to zwrócić specjalną uwagę, podobnie bowiem jak to ma miejsce w wypadku dwóch opowieści o stworzeniu człowieka, tak samo dwa opowiadania o stworzeniu świata niosą ze sobą odmienne przesłania. Nie tylko więc opowieść o stworzeniu człowieka, ale cała opowieść o stworzeniu ma strukturę dylematu. Strukturę dylematu ma więc przede wszystkim opowieść o stworzeniu świata przed stworzeniem człowieka. Inny obraz świata wyłania się z jednej, a inny - z drugiej opowieści. Ważniejsze jednak

26 Interpretacja religijna zgodzi się na taką formułę pod warunkiem jej uzupełnienia: postępuj jak uważasz, ale uważaj na nieuchronną karę.

27 Podkreślające ową dwoistość śródtytuły pochodzą od oficjalnych, religijnych redaktorów tekstu; por. śródtytuł „Drugi opis stworzenia człowieka”.

28 Połączenie (przypadkowe?) tekstu ,,jahwisty” z tekstem ,elohisty”. 
- nie tylko z religijnego, ale również z filozoficznego i kulturowego punktu widzenia, jest to, że z każdej z tych dwóch opowieści wyłania się odmienny „obraz Boga”29. Właśnie ta odmienność (podobnie jak odmienność obrazów Boga i obrazów człowieka w dalszej części opowieści) składać się będzie na antynomiczność całego biblijnego przekazu, osnutego wokół mitu o stworzeniu.

Instrument Platoński (Sokratejsko-Platoński), zapożyczony z Eutyfrona, będzie zastosowany do odczytania obu opowieści o „stworzeniu człowieka", tam bowiem mówi się wprost - i to na dwa sposoby - o dobru $^{30}$ i Bogu. Pośrednio jednak można go również zastosować do opowieści o „stworzeniu świata”. Ale najpierw spróbujmy wydobyć same opowieści i różnicę między nimi.

Warto zacząć od „drugiego opisu stworzenia człowieka”, który jest zarazem częścią drugiego opisu stworzenia świata. Świat, według tego drugiego opisu, stwarzany jest nad wyraz arbitralnie: najpierw „niebo i ziemia", potem, w roli człowieka, mężczyzna, dalej rośliny, po nich zwierzęta i na koniec kobieta. Tymczasem w pierwszym opowiadaniu kolejność stwarzania jest znacznie mniej ekstrawagancka i odpowiada w ogólnych zarysach kolejności, w jakiej wszechświat rozwijał się wedle tego, co na ten temat mówi nauka - czy to będzie „oddzielenie światła od ciemności”, czy wody od lądu, czy „stworzenie” roślin, czy zwierząt morskich i lądowych i w końcu człowieka. Właściwie tylko słońce i księżyc wyłamują się w tej opowieści z „naukowego” kanonu, stworzone zostały bowiem dopiero po roślinach. Ten „drobny” incydent pomińmy (znawcy mitologii ludów świata zapewne to odchylenie od „normalnego” przebiegu kosmogenezy potrafią objaśnić), cały bowiem pozostały przebieg ewolucji zdaje się sugerować, że jeśli nawet „Bóg” „stwarza z niczego" (czego tekst w żaden sposób nie przesądza ${ }^{31}$ ), to

29 Jest wielce symptomatyczne, że tzw. kreacjoniści, deklarujący wierność literze „pisma świętego”, nie zauważają, że są w nim zawarte dwie opowieści o stworzeniu świata, i odwołują się tylko do tej bliższej kanonowi religijnemu.

30 O tym, że coś ,jest dobre” (bo ktoś to uważa za dobre) mówi się już na samym początku. Ponieważ jednak coś, co jest (zawsze według kogoś) dobre, to nie to samo, co samo dobro, przyjmuję, że o dobru mowa będzie dopiero w opowieści o stworzeniu człowieka.

31 Jeśli by nawet przesądzał, to $\mathrm{z}$ filozoficznego punktu widzenia (odmiennie niż z naukowego, jako że nauka nie dotyka absolutnego początku, a nieabsolutny początek zawsze jest czymś) nie jest to jakoś szczególnie religijny pogląd. Doświadczenie metafizyczne, a raczej to, co się w toku tego doświadczenia wyłania, a zarazem 
jednak najwyraźniej nie stwarza arbitralnie, lecz zgodnie z prawami przyrody: ponad nim jest jakieś prawo. Tymczasem Bóg z drugiego opisu nie dopuszcza nad sobą żadnego prawa, całym prawem jest tu jego własna wola - bo tylko tak daje się wytłumaczyć stworzenie mężczyzny na pustym miejscu i tworzenie pozostałych elementów świata już właściwie „pod niego"32. W drugim opisie również pojawia się kwestia prawa, i to jeszcze dobitniej, niż w opisie pierwszym, ale w przeciwieństwie do tamtego, najwyższego prawa (prawa ponad jakimkolwiek z osobna wziętym podmiotem), jest to właściwie tylko jakoś sformalizowana (ujęta w formę zakazu) wola Najwyższego Prawodawcy.

Oto pierwszy (przynajmniej pierwszy w kolejności narracji) dylemat biblijny: prawo ponad stwórcą czy najwyższy prawodawca (najwyższy autorytet) ponad prawem, albo, w języku bardziej religijnym, prawo ponad bogiem, czy bóg ponad prawem? Albo jeszcze inaczej - czy istnieje jakikolwiek podmiot, choćby się nazywał „Bóg”, który może w pojedynkę stanowić prawo, czy, przeciwnie, nie istnieje żaden taki podmiot?

W ten sposób Bóg został już wstępnie zdefiniowany: jest to albo ktoś, kto liczy się z prawem, albo ktoś, kto każe innym liczyć się z jego arbitralną wolą. To jest filozoficzna, bo antynomiczna, odpowiedź na pytanie o Boga, sformułowana w języku mitu. A czym jest prawo, oprócz tego, że jest to coś, z czym się liczy albo i nie liczy się podmiot? O tym szerzej traktuje, bardziej od poprzedniej udramatyzowana, opowieść o stworzeniu człowieka.

A dokładniej - dwie opowieści.

wytwarza, wyłania się i wytwarza w dosłownym sensie ,z niczego”. Naukowy uraz na punkcie „stwarzania z niczego" wynika z zapoznania różnicy między przedmiotem nauki i przedmiotem filozofii. Różnicę tę zresztą całkowicie świadomie zaciera religia, która dokonuje swojej ideologicznej operacji na przedmiocie filozofii. Przejście od ideologii (od religii) do filozofii będzie możliwe, gdy zapytamy, kto właściwie, i w jakim trybie (a kogo zbiorczo religia nazywa „Bogiem”), „stwarza świat z niczego", w przeciwieństwie do „zwykłego” twórcy, który stwarza zawsze coś z czegoś. W sprawie metafizycznej relacji z wytwarzania bytu w trybie doświadczenia metafizycznego i metafizycznego wyboru zob. W. Paradowska, R. Paradowski, Universal Pattern of Culture and the Dialectical Metaphysics of Choice, „Dialogue and Universalism" 2009, No 10.

32 „Sentymentalne” teologiczne wyjaśnienie „celu” stworzenia jest bliskie tej konstatacji, ale cały sentymentalizm pryska, gdy widzimy, co właściwie zostało stworzone. 
Pierwsza jest nad wyraz lapidarna. Nie ma w niej ,prochu ziemi”, nie ma „tchnienia życia”, zakazu spożywania owoców ani relatywizacji wartości kobiety - wszystkiego tego, i paru jeszcze innych rzeczy, które są w opowiadaniu drugim. Ale jest za to coś, czego wyraźnie w opowiadaniu drugim brak (i co uzupełnimy, nie ukrywam tego, w drodze interpretacji): jest mianowicie „obraz Boży”. Od razu powiedzmy, co się na ten obraz Boży nie składa - nie składa się to wszystko, co jest treścią drugiego opowiadania o stworzeniu człowieka, a więc ani glina, ani drzewo zakazu, ani drugorzędność kobiety. Na obraz Boży składają się mężczyzna i niewiasta nie usytuowani względem siebie hierarchicznie, mężczyzna i kobieta, którym nie zakazano spożywania „owoców z drzewa wiadomości złego i dobrego", mężczyzna, któremu ani nie zabroniono „słuchać swej żony”, ani nie nakazano panować nad nią, i kobieta, której uczuć nie zmrożono słowami „ku twemu mężowi będziesz kierowała swe pragnienia, on zaś będzie panował nad tobą"33. Na obraz Boży składają się równi sobie i nikomu nie podlegli kobieta i mężczyzna. Nie trzeba dodawać, że ten „obraz Boży” nie jest obrazem religijnym ${ }^{34}$.

Ale jest jeszcze jeden „obraz”. Ciekawe, że nie jest to, zgodnie z intencją pierwotnych redaktorów opowieści, „obraz Boży”. W żadnym miejscu „drugiego opisu stworzenia człowieka” termin ten nie występuje. Chociaż występuje, jako „aktor”, stwórca, występuje „Pan Bóg”, stwarzający człowieka, występuje przede wszystkim produkt owego stwarzania; dlatego i tu, wbrew zrozumiałej powściagliwości pierwotnych redaktorów, mamy do czynienia z obrazem Bożym. Tyle że to już zupełnie inny „obraz”35.

33 Rdz 3, 16.

34 Religijny jest za to obraz narysowany przez Pawła z Tarsu (,świętego Pawła"), wedle którego mężczyzna jest głową kobiety.

${ }^{35}$ To interpretacyjne odtworzenie ,obrazu Bożego” nr 2, oznaczającego Boga jako symbol porządku (w tym porządku wartości) nakreślonego w drugim opowiadaniu, nie zmienia faktu, że jeśli nawet „Bóg” jest symbolem zarówno człowieka z pierwszego opowiadania, jak i z drugiego, to jednak tylko regule, zawartej w opowiadaniu pierwszym, zresztą religijnie dysfunkcjonalnej, przypisano status „Boski” („obraz Boży”), status ,złotej reguły”. Widocznie, wbrew religii, obie reguły mają status kulturowy, ale tylko jedna z nich ma oprócz kulturowego, a więc partykularnego, jeszcze status ,uniwersalny” - elementom ,hierarchii stworzenia” przysługuje coś więcej niż tylko to, co jest związane z ich miejscem w hierarchii. Nawiasem mówiąc, religia (tu - chrześcijaństwo) tego nawet specjalnie nie neguje, ale tym nie mniej pozbawia jakiegokolwiek praktycznego znaczenia, umieszczając działanie tej uniwersalnej reguły „w niebie”, „w zaświatach”, „na tamtym świecie”, ogólnie 
Wprawdzie już nie „na swój obraz”, tym nie mniej „stworzył” Bóg człowieka, zresztą „,z prochu ziemi”. To zresztą nie ma specjalnego znaczenia; gdyby w poprzednim przypadku - w przypadku stwarzania opisanego w pierwszym opowiadaniu - do ,prochu ziemi” opis się odwołał, też nie miałoby to specjalnie znaczenia ${ }^{36}$. Co innego natomiast ma znaczenie - to mianowicie, że o ile wedle pierwszego opowiadania Bóg jako człowieka stworzył mężczyznę i niewiastę, o tyle tu, w opowiadaniu drugim, tylko mężczyznę ${ }^{37}$ - mężczyzna, bez konieczności dopełnienia przez kobietę, wypełnia sobą pojęcie człowieczeństwa, jest ekwiwalentem pojęcia „człowiek”38. Zaznaczmy na marginesie, że łączenie obu opowieści w jedną nie może się obyć bez zacierania tej zasadniczej różnicy, różnicy między człowieczeństwem, równo podzielonym między kobietę i mężczyznę, a człowieczeństwem, w całości skumulowanym w mężczyźnie. Religia zaciera tę różnicę przez to, że jej nie podkreśla, zarazem organizując swój dyskurs wokół opowiadania drugiego.

A drugie opowiadanie to przede wszystkim - w trybie narracji mitycznej - drzewo wiadomości złego i dobrego oraz ,żebro”, z którego stworzona została kobieta. W trybie narracji symbolicznej to po pierwsze podział kompetencji w kwestii definiowania dobra i, po drugie, niski status kobiety i w efekcie - ustanowienie porządku hierarchicznego, alternatywnego wobec niehierarchicznego porządku, zarysowanego, ale jeszcze nie do końca ustanowionego, w pierwszym opowiadaniu.

Elementy hierarchii pojawiają się już w samym sposobie stwarzania (Bóg stwarza człowieka jak garncarz stwarza garnek) oraz w sposobie

- w sferze transcendencji religijnie rozumianej. Religijna operacja na regule pierwszej polega nie tylko na przeniesieniu jej działania jako reguły uniwersalnej w pozaziemską sferę, ale również na odmówieniu jej statusu kulturowego (mężczyzna i kobieta, i w ogóle wszyscy, mogą być równi tylko wobec Boga, a poza tym mogą być i są nierówni; kultura, w której byliby rzeczywiście równi, jakaś kultura równości wobec prawa itp., nie jest według religii możliwa).

${ }^{36}$ Może nie do końca - w opowiadaniu pierwszym, gdzie jest mowa o stwarzaniu człowieka jako bytu wyższego (,na obraz” itd.), człowiek jest stwarzany ,z niczego", w drugim jako tylko kulturowy - z czegoś. Regułę porządku, wartość podstawową „stwarza się" bowiem „z niczego".

37 Już choćby z tego powodu opowiadania te, jeśli są nawet komplementarne, to tylko w takim znaczeniu, w jakim komplementarne są człony alternatywy, nie zaś w prostym znaczeniu dopełniania.

38 Abstrahując od okoliczności kulturowych można powiedzieć, że to samo odnosiłoby się - przy odwróceniu ról - do kobiety, która, bez konieczności dopełnienia przez mężczyznę, byłaby synonimem pojęcia „człowiek”. 
obchodzenia się ze „stworzeniem” (wziął je i umieścił ${ }^{39}$ ). Pozbawienie człowieka jakiejkolwiek kompetencji w rozstrzyganiu co dobre, a co złe (oprócz „kompetencji” bycia posłusznym) ${ }^{40}$ ową hierarchię ustanawia ostatecznie: wyższy szczebel hierarchii to ten, gdzie te kwestie są rozstrzygane, a niższy - ten, gdzie to rozstrzygnięcie obowiązuje. Człowiek milcząco przyjmuje do wiadomości zakaz naruszania kompetencji wyższego szczebla, tym bardziej, że został on expressis verbis obwarowany groźbą najwyższego wymiaru kary. Kompetencji wyższego szczebla hierarchii nie wolno kwestionować pod groźbą śmierci.

Na pierwszy rzut oka może się wydawać, że opowieść o zakazie spożywania owoców z drzewa wiadomości złego i dobrego nie przesądza jeszcze o tym, że Bóg (Bóg z tego opowiadania) jest ponad dobrem, że definiowanie dobra należy do jego wyłącznej kompetencji. Można by powiedzieć, pochopnie zresztą, że Bóg przekazuje tylko człowiekowi jakąś wyższą normę. Jednak fakt, że kompetencja człowieka w tym względzie została wykluczona, oraz brak w horyzoncie opowiadania jakiegokolwiek innego możliwego źródła, powoduja, że źródłem takim (przy czym źródłem jedynym) może być tylko sam autor zakazu i nadawca groźnego komunikatu. Najwyraźniej więc Bóg jest tu ponad dobrem. W pierwszym opowiadaniu ani on nie jest wyraźnie ponad dobrem, ani dobro nie jest ponad nim, ale przynajmniej druga $\mathrm{z}$ tych możliwości, inaczej niż w opowiadaniu drugim, nie jest wykluczona. Chociaż - może trochę więcej, niż tylko niewykluczona. Wiemy wprawdzie, że to, iż coś jest według kogoś dobre (a według Boga wszystko, co stwarzał w pierwszym opowiadaniu, było dobre), nie oznacza, że jest dobrem samym, ale wiemy też, że jeśli nawet stwarzał „z niczego "41, nie stwarzał wedle wzoru przez siebie jednostronnie ustanowionego ${ }^{42}$.

39 Zob. Rdz 2, 15.

40 Zob. Rdz 2, 17.

41 Nie jest to, jak już zasygnalizowano wyżej, jakaś szczególnie „teologiczna” zdolność, zważywszy na to, że byt wyższy w ogóle jest stwarzany „z niczego” (tego, z czego jest w ogóle wytwarzany byt, nie wiemy i nigdy się pewnie nie dowiemy, chociaż być może również ,z niczego”). O tym, przez kogo, z czego i w jaki sposób jest wytwarzany byt wyższy (a w sensie filozoficznym również byt w ogóle) opowiada metafizyka dialektyczna.

${ }^{42}$ Religijny pogląd na tę sprawę byłby taki, że wedle wzoru danego przez wyższego Boga. Monoteizm nie może oczywiście zaakceptować takiego rozwiązania, chociaż chrześcijański wariant monoteizmu na coś takiego wskazuje, każąc „Synowi Bożemu" demonstrować posłuszeństwo wobec boskiego Ojca. Tak czy inaczej ani 
Hierarchię wyznacza zakaz (oczywiście w połączeniu z przemożną siłą tego, kto go formułuje), ale to jeszcze nie cała hierarchia, chociaż zarazem zakaz wyznacza zasadę hierarchii: o sprawach niższego szczebla (w każdym razie tych najważniejszych, ale też o tym, które są najważniejsze) decyduje szczebel wyższy ${ }^{43}$.

Pozostałe szczeble hierarchii, naturalne z punktu widzenia kultury pasterskiej i koczowniczej, dziś robią szokujące wrażenie, nic dziwnego więc, że ten aspekt „stworzenia człowieka” nie jest specjalnie eksponowany: Bóg, zatroskany samotnością mężczyzny, postanowił „uczynić odpowiednią dla niego pomoc”44. Wystarczy nie czytać „Pisma świętego" by wiedzieć, że Bóg stworzył w związku z tym kobietę. Rzecz w tym jednak, że nie jest to wiedza oparta na tekście. Tekst mówi bowiem co innego: mężczyźnie, czyli człowiekowi, Bóg stworzył do pomocy zwierzęta, i dopiero konstatacja, że pośród zwierząt „nie znalazła się pomoc odpowiednia dla mężczyzny"45, spowodowała, że przedsięwziął Bóg znane czynności anestezjologiczne, a następnie chirurgiczne, i stworzył kobietę, lepiej, zapewne, od zwierząt, spełniającą kryterium bycia pomocną człowiekowi, skoro z takim entuzjazmem odniósł się on do najnowszego boskiego wynalazku. Może kobieta lepiej, niż zwierzęta, spełnia oczekiwania mężczyzny, ale nie wiadomo, czy na pewno i czy zawsze spełnia je lepiej, dlatego hierarchia, w której na górze jest władza najwyższa, albo podmiot najsilniejszy (,wszechmocny”, ten co może zakazywać pod groźbą śmierci), dalej człowiek, w którego roli występuje tu mężczyzna, a następnie, w zależności od tego, co akurat mężczyzna uzna za bardziej mu pomocne, zwierzęta lub kobieta, ta hierarchia nie jest $\mathrm{w}$ dolnych partiach wyraźnie określona. Ta hierarchia to jednocześnie „człowiek”. Tam, w pierwszym opowiadaniu, człowiek to mężczyzna i kobieta ${ }^{46}$, hierarchicznie niezróżnicowani, mający „nad sobą”47 jedynie „Boga” jako symbol owego niezróżnicowania; tu, w opo-

przyznanie wyłącznej kompetencji jedynemu Bogu, ani przeniesienie jej na Boga wyższego nie jest jedynym rozwiązaniem tego problemu proponowanym przez przekaz zawarty w Księdze Rodzaju.

43 Oto dlaczego tzw. zasada subsydiarności nie należy do porządku demokratycznego.

${ }_{44} \mathrm{Rdz} 2,18$.

$45 \mathrm{Rdz} 2,20$.

$46 \mathrm{Rdz} 1,27$.

47 W cudzysłowie, bo relacja między symbolem i tym co symbolizowane nie jest hierarchiczna. 
wiadaniu drugim, sam „stwórca” to władza najwyższa, władza nad mężczyzną (jakiś inny mężczyzna dysponujący większą władzą, większą siłą), potem władza mężczyzny nad kobietą i zwierzętami, i ogólnie - nad dobytkiem. Wprawdzie, jak stwierdzono wyżej, samo pojęcie „obraz Boży" w drugim opowiadaniu nie występuje, skoro jednak występuje Bóg jako aktor, można bez ryzyka popełnienia błędu powiedzieć (chociaż pierwotni redaktorzy ${ }^{48}$ tego nie powiedzieli), że tak jak w pierwszym przypadku Bóg symbolizuje człowieka pojętego niehierarchicznie, jako równych sobie kobietę i mężczyznę (albo, odpowiednio, jakiekolwiek podmioty jakiejkolwiek konkretnej relacji), tak w drugim przypadku jest symbolem tych samych (i wszelkich innych) podmiotów odniesionych do siebie hierarchicznie ${ }^{49}$. Podmiotów, z których jeden jest każdorazowo podmiotem władzy, drugi zaś jej przedmiotem, deklarującym tamtemu posłuszeństwo. Człowiek według tego opowiadania został również stworzony na „obraz Boży”, z tym, że to zupełnie inny obraz, inny wzór. Inny wzór kulturowy. Zarazem wzór, do którego odwołuje się religia.

Ale to jeszcze nie koniec historii stworzenia. To dopiero coś w rodzaju uwertury, albo pierwszego rozdania. Wiemy już, że „Bóg” może symbolizować prymat prawa i prymat dobra (chociaż ta fundamentalna kwestia wymaga jeszcze rozwinięcia), może też symbolizować prymat władzy, prymat siły. Zwłaszcza kwestia dobra - prymatu dobra nad władzą - wymaga rozwinięcia, nie została bowiem w pierwszym opowiadaniu o stworzeniu człowieka należycie wyakcentowana. Całe pierwsze opowiadanie wymaga konkretyzacji i rozwinięcia. W dalszym ciągu historii

48 Raczej jednak autorzy, jeśli się oczywiście zgodzimy, że ta kompozycja mitów ma autorski charakter. Stanowisko religijne skłania się raczej do ,redaktorstwa", a nawet prostego pisania pod dyktando Boga. I tu można się znów (i znów częściowo) zgodzić z interpretacją religijną: księga była niewątpliwie „objawiona”, jeśli pod „objawieniem” rozumieć artystyczne natchnienie, niezbędne do napisania, czy choćby tylko skomponowania, tak wielkiego dzieła. Filozoficzna (antynomiczna) forma opowieści o stworzeniu nie może być w żadnym razie dziełem kompilatorskim, nie może być przypadkowym wynikiem składania różnych wersji mitu przez różnych autorów piszących w różnych czasach.

49 Rygorystycznie odczytana opowieść o antropogenezie pozbawia właściwie religię „obrazu Boga”, zważywszy jednak na to, że fillozofia nie jest zainteresowana już tym pojęciem (filozofia Księgi Rodzaju jeszcze była), nic nie stoi na przeszkodzie przyznaniu religii prawa do posługiwania się tym pojęciem - stąd rozciągnięcie go w niniejszym wywodzie na to, co zgodnie z intencją twórców Księgi Rodzaju takim obrazem nie jest (człowiek hierarchiczny nie jest „obrazem Boga”). 
stworzenia ciąg dalszy zyskały zresztą oba opowiadania. Chodzi o jedną z najsłynniejszych opowieści biblijnych, o historię zerwania owocu.

Czasy, w jakich Izraelici składali mity biblijne, to czasy męskiej kultury pasterskiej, koczowniczej, patriarchalnej. Bóg absolutnej władzy męskiej to Bóg tej kultury. Nie dziwi, gdy tworzy swoje dzieło z gliny, nie dziwi, gdy dziełu swojemu narzuca swoją arbitralną władzę, a z nią swoje reguły, gdy grozi śmiercią za ich nieprzestrzeganie. Dlatego pojawienie się kobiety, kwestionującej tę władzę i te reguły, zapowiada zwrot akcji. Kobieta swą niesankcjonowaną pracą myślową rzuca wyzwanie arbitralnej władzy i władza, przynajmniej w pierwszym odruchu, usiłuje przywołać ją do porządku. Władza pokazuje, gdzie jest jej miejsce, rzucając na nią klątwy.

Interpretacja religijna upiera się przy tym, że klątwy rzucane są przede wszystkim na węża, chociaż nie wydaje się, by Bóg, niezależnie, czy Bóg równego statusu mężczyzny i kobiety, czy Bóg hierarchii i posłuszeństwa - tu akurat Bóg posłuszeństwa - miał się zniżać do pojedynku z wężem. Nawet jeśli byśmy uznali, że symbolizuje on szatana, chociaż nic (oprócz religijnej interpretacji tekstu) na obecność tej postaci w „rajskim ogrodzie" nie wskazuje. Przy jeszcze jednej kwestii upiera się, i tym razem upiera się słusznie, interpretacja religijna. Praca myślowa, niesankcjonowana praca myślowa, jest rzeczywiście, z punktu widzenia Boga hierarchii i zakazu, nieposłuszeństwem, niezależnie od tego, czy kobieta samodzielnie zakwestionowała absolutną legalność boskiego zakazu, czy została do tego namówiona przez jakieś inne (oprócz jej własnego rozumu) ciemne siły ${ }^{50}$. Rzeczywiście zakwestionowanie boskiej władzy i spożycie owocu jest nieposłuszeństwem, ale tylko z punktu widzenia tej władzy - z punktu widzenia, zarysowanego w drugim opowiadaniu o stworzeniu człowieka, porządku hierarchicznego, a także z punktu widzenia nie liczącej się z żadnym wyższym prawem siły, ukazanej (jako „stwórca”) w drugim opowiadaniu o stworzeniu świata i człowieka. W reakcji na nieposłuszeństwo Bóg z drugiej opowieści uściśla zasady hierarchicznego porządku, wśród których jest przede

50 Mamy tu niewątpliwie do czynienia z ciemną siłą, ciemniejszą niż tylko trywialne nieposłuszeństwo arbitralnej władzy, siłą, przeciwstawiającą się największej sile przyrody - instynktowi samozachowawczemu (to aspekt „negatywny” tej „siły”), a zarazem siłą, przekształcającą naczelne w człowieka (aspekt „,pozytywny”). Tą „ciemną siłą" może być wolność. Skoro już dopisujemy coś do słownika symboli, to tę właśnie siłę symbolizuje tu wąż. 
wszystkim zakaz samodzielnego używania rozumu ${ }^{51}$ (klątwa rzucona jest na węża, uosabiającego pracę myślową i alter ego wewnętrznego dialogu) oraz zakaz wstępowania w relacje niehierarchiczne (tu: między

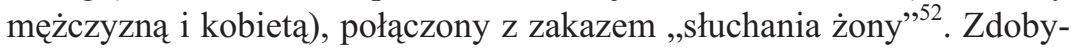
wanie pożywienia $\mathrm{w}$ pocie oblicza czy trud brzemienności, a nawet obrócenie się w proch, na które powołuje się najczęściej dyskurs religijny, to tylko drugorzędny materiał narracyjny, wszystko to bowiem i tak zapewnia człowiekowi natura, gdy tymczasem potępienie rozumu i relacji niehierarchicznej wystarczająco określają pewnego typu „tradycyjny” porządek kulturowy. Mimo to jednak, mimo przemilczenia ufundowanej tu kultury hierarchii i nierówności, to właśnie tę kulturę aprobuje dyskurs religijny, odnosząc się pozytywnie do potępienia „węża”. Czym innym, jak nie ideologią potępienia nieposłuszeństwa najwyższej władzy, nieposłuszeństwa wobec najwyższego autorytetu, jest religia, jest religijna interpretacja biblijnego dylematu?

Bo i tu jeszcze mamy ciagle do czynienia $\mathrm{z}$ dylematem: albo potępienie nieposłuszeństwa, albo aprobata dla antropogenezy, rozumianej jako przełamanie absolutnej determinacji samozachowawczego instynktu, jako wolność wyboru odmiennego systemu wartości. Możliwość i wolność (a właściwie również konieczność) wyboru ukazana zastała od razu w strukturze (w podwójnej strukturze) opowieści, ukazującej z jednej strony prawo i równe statusy stron jako wartości podstawowe, $z$ drugiej autorytet i posłuszeństwo, również jako takie wartości, w obu przypadkach symbolizowane przez Boga. Wydaje się oczywiste, że „Bóg” prawa i równego statusu, i „Bóg” autorytetu i posłuszeństwa muszą się wzajemnie wykluczać.

Opowieść o spożyciu owocu ukazuje Boga zarazem jako ewoluująca $\operatorname{postac}^{53}$, jak i jako symbol obu głównych wartości ${ }^{54}$. Po spełnieniu swego

51 To pierwsza formuła na oznaczenie tej specyficznej ,siły”, którą symbolizuje wąż: własny rozum w przeciwieństwie do rozumu „wyższego" (1); kolejne to wybór porządku kulturowego (2) i wybór metafizyczny - wytworzenie reguły (3). W porządku metafizycznym kolejność jest akurat odwrotna. Zob. W. Paradowska, R. Paradowski, Universal Pattern of Culture and the Dialectical Metaphysics of Choice, op. cit. Kiedy kobieta mówi „wąż mnie zwiódł”, mówi właściwie - „tak mi podpowiada mój rozum”.

52 Zob. Rdz 3, 17.

53 Jako ewoluującą postać literacką ukazuje Boga Jack Miles w książce Bóg. Biografia, Warszawa 1998.

Na poziomie kulturowym wąż mógłby symbolizować oba systemy wartości (jedność przeciwieństw), na poziomie metafizycznym - wybór-ustanawianie wartości podstawowych. 
przykrego obowiązku kulturowego - po tym, jak zasady kultury hierarchii, posłuszeństwa i autorytetu zostały sformułowane, a kultura oparta na tych tradycyjnych wartościach - ustanowiona, Bóg ukazuje siebie wprost jako symbol całkiem odmiennego systemu wartości, systemu opartego na wzajemnym uznaniu równego statusu stron, na wzajemnym uznaniu ich równej kompetencji do rozstrzygania o dobru i złu, i ostatecznie, równej kompetencji do stanowienia prawa. „Oto człowiek stał się taki jak My, zna dobro i zło" "55. Oto wskazówka - biblijna wskazówka! - dla zwolenników religijnie ugruntowanych filozofii dialogu (kontynuatorów Bubera i Levinasa), którzy w stopniu niewystarczającym uniwersalizują tę kategorię, wyłączając $\mathrm{z}$ niej Boga jako najwyższy autorytet, przez co tego rodzaju filozofie dialogu sytuują się w dalszym ciągu po stronie religii jako ideologii autorytetu (jako ideologii autorytarnej), nie stając się, wbrew nazwie, filozofiami par excellence. Tymczasem Biblijny Bóg idzie dalej, uznając sam siebie za stronę, za równą innym stronę dialogu o wartościach. Ale i to najwyraźniej nie jest Bóg religii, skoro przymierze, które człowiekowi zaproponował jako formę kulturową wzajemnie równego traktowania, wzajemnego uznania równych kompetencji do definiowania dobra i stanowienia prawa, przedefiniowano w dyskursie religijnym w jakiś rodzaj jeszcze większego oddania, bezwarunkowego oddania człowieka Bogu (a Boga jako strony przymierza w Boga składającego człowiekowi obietnicę ${ }^{56}$ ). Tak więc nawet przymierze jest $\mathrm{w}$ religii interpretowane $\mathrm{w}$ świetle opowiadania i przesłania o Bogu autorytetu, Bogu ponad prawem, chociaż „Pismo” dostarcza do wyboru innego klucza, z pomocą którego problem ten może być rozwiązany w sposób bardziej adekwatny. Jednak religia i religijna interpretacja takiego właśnie wyboru wartości dokonuje: spośród przedstawionych do wyboru przez dylemat biblijny wartości podstawowych (wartości autorytarnych i nieautorytarnych) wybiera wartości autorytarne: prymat autorytetu nad prawem, wyłączną kompetencją władzy do definiowania dobra, a nawet prymat autorytetu nad przymierzem (to już w Nowym Testamencie, chociaż opis relacji między Bogiem i Abrahamem, a zwłaszcza Bogiem i Noem, ale także Bogiem, Mojżeszem i ludem, też nie eksponuje specjalnie wyrazistości i odrębności typologicznej przymierza). Jeśli wartości takie są eksponowane w „świętej księdze” obok, jak wykazaliśmy, wartości im przeciwnych, i te właśnie, autory-

${ }_{56} \mathrm{Rdz} 3,22$.

56 Zob. Ga 3, 15-22. 
tarne wartości, są przez religię wybrane, i z nimi właśnie utożsamia się religia, to pytanie, czy legitymizowanie porządku autorytarnego albo integrowanie społeczeństwa na bazie tych wartości jest swoiste czy nieswoiste, jest pytaniem czysto retorycznym.

Ciągle natomiast nie jest retoryczne pytanie o transcendencję. Wiemy już (o ile nie wiedzieliśmy do tej pory), że Bóg, którego religia i religijne religioznawstwo utożsamiają $\mathrm{z}$ transcendencją, jest tylko kulturowym symbolem, i to nie całej transcendencji, a jedynie jej części. Ściślej zatem rzecz biorąc, Bóg religii jest częścią religii (elementem religijnego dyskursu), a formą kulturową odpowiedniej części transcendencji nie jest sam Bóg, lecz cała religia - a jak wiadomo, nie każda posiłkuje się nawet pojęciem Boga. Jeśli chcielibyśmy - wstępnie - określić transcendencję posiłkując się pojęciem Boga, to zgodnie z Księgą Rodzaju Starego Testamentu musielibyśmy odwołać się aż do trzech takich pojęć: Boga arbitralnego definiowania dobra, Boga posłuszeństwa (,z drzewa poznania dobra i zła nie wolno ci jeść”) (1), Boga równych kompetencji w definiowaniu dobra („Oto człowiek stał się taki jak My, zna dobro i zło") (2) i jeszcze na dodatek Boga najważniejszego: Boga wyboru między tymi dwoma wzajemnie wykluczającymi się regułami (3). Tylko pierwszy z nich jest Bogiem religii i legitymizowanych przez nie porządków kulturowych i politycznych. Jest więcej niż pewne, że chodzić tu może wyłącznie o porządki autorytarne.

Dwaj pierwsi „Bogowie”, chociaż odniosłem ich tu do szeroko pojętej transcendencji, są w istocie „bogami” określonych porządków kulturowych i politycznych - autorytarnego i nieautorytarnego. Tylko trzeci z nich jest, w sensie ścisłym, „Bogiem” transcendencji (tylko ten bezpośrednio symbolizuje transcendencję), bo tylko wolny wybór między porządkami (o ile rzeczywiście jest wolny, a wolny jest wtedy, gdy nie jest zdeterminowany przez kulturowe i polityczne naciski) jest transcendencją samą. Jeśli religia jest zbudowana na dominacji, hierarchii i posłuszeństwie - a nic nie wskazuje na to, by miało być inaczej - to $\mathrm{z}$ transcendencją ma tyle wspólnego, że zrzeczenie się wolności (zawsze zresztą odwoływalne) i opowiedzenie po stronie dominacji, hierarchii i posłuszeństwa, przy wszystkich możliwych naciskach kulturowych i politycznych, jest samo w sobie wolnym, transcendentnym aktem, którego te naciski nie usprawiedliwiają.

Cały niezbędny materiał dla powyższych konstatacji daje się wydobyć z antynomicznej konstrukcji starotestamentowej. I już ta starotestamentowa konstrukcja pokazuje, że religijny ideologiczny wybór zubaża 
kulturową i transcendentną strukturę „boskości” - o ile byśmy chcieli poważnie traktować tę formę językową.

Rzecz w tym jednak, że nie musimy. Odwołanie się do Boga i boskości nie jest jedynym sposobem uchwycenia transcendencji - abstrahując już od tego, że odwołanie się w sposób konsekwentny do tej symboliki (choćby w związku z rzetelnym odczytaniem uchodzącego powszechnie za religijny tekstu) nie pozostawia nic z religijnej „tajemnicy”. Transcendencję można uchwycić językiem filozofii, bez odwoływania się do mitologicznej terminologii - a „Bóg” i „boskość” należą niewątpliwie do języka mitu. „Boga” i „boskość” „odciął” już zresztą raz na zawsze Ockham. Nie zmienia to zresztą w niczym wysokiej oceny, wystawionej tu dialektycznej strukturze biblijnej koncepcji transcendencji, przedstawionej skądinąd z pomocą języka mitu, a więc jednocześnie z pomocą pojęcia Boga i obrazu Boga ${ }^{57}$.

Rozważmy jednak jeszcze kwestię rozłączności i połączenia samych regul.

Stwierdziłem wyżej, że religia zasadza się na dominacji, hierarchii i posłuszeństwie. Zasadniczo rzecz biorąc nie wypiera się tego nawet sam religijny dyskurs, chociaż jego eksponenci wolą mówić o miłości. Ponieważ „obraz Boga” mówi o równym traktowaniu kobiety i mężczyzny, albo lepiej - o traktowaniu się wzajemnie przez mężczyznę i kobietę jak równych, a religia, choć to obraz nie religijny, wykorzystuje go w swym dyskursie, odwołując się również do przykazania miłowania bliźniego jak siebie samego, można powiedzieć, że kwestia „miłości” wchodzi w zakres wartości religijnych. Trzeba oczywiście uściślić, co się przez miłość rozumie, żeby ostatecznie odpowiedzieć na pytanie, czy religia, w tym wypadku chrześcijaństwo, jest ideologią miłości, czy ideologią posłuszeństwa, a jeśli jednego i drugiego, to na czym w chrześcijaństwie polega owo połączenie.

Przykazanie miłowania bliźniego jak siebie samego jest regułą starotestamentową ${ }^{58}$, jedyną, która ma w swej strukturze mechanizm regulujący jej stosowanie ${ }^{59}$, podczas gdy wszystkie pozostałe z górą sześćset

57 Wysokiej oceny dialektycznej struktury mitu o stworzeniu nie należy mechanicznie przenosić na pozostałe części Biblii, chociaż szersze zastosowanie tego klucza interpretacyjnego może skądinąd okazać się płodne.

58 Kpł 19, 18.

59 Odwołanie do „miłowania siebie samego”, a więc wymogu równego i dobrego traktowania siebie i innego. 
przykazań mają formę zakazu lub nakazu, odwołującego się do strachu przed Bogiem. Tym samym przykazanie miłowania itd., nie zasadzające się na wymaganiu jednostronnym, ale na wymaganiach wzajemnych, może być traktowane jako reguła przeciwstawna regule posłuszeństwa. Należy odnotować, że w starotestamentowym dekalogu przykazanie miłowania bliźniego w ogóle się nie pojawia, co może oznaczać, że pomimo iż daje się wyprowadzić jako reguła podstawowa (jedna z dwóch reguł podstawowych) z pierwszej opowieści o stworzeniu człowieka, nie została ostatecznie w żadnej z pozostałych ksiag starotestamentowych tak potraktowana. Dodajmy, że „miłowanie” nie pojawia się w starotestamentowym dekalogu pod żadną postacią, co warte jest odnotowania jeszcze $\mathrm{z}$ tego powodu, że $\mathrm{w}$ dekalogu chrześcijańskim pojawia się aż pod dwoma postaciami. Najpierw jednak pojawia się w ewangelii Mateusza, początkowo w zaleceniu miłowania nieprzyjaciót $1^{60}$, a potem w przypowieści o „największym przykazaniu" "61. Tym największym przykazaniem ma być „miłowanie Pana Boga całym sercem itd.” oraz „drugie podobne temu” - „miłowanie bliźniego jak siebie samego”. Już uznanie drugiego za podobne pierwszemu musi budzić czujność interpretacyjną, zważywszy na to, że drugie - „będziesz miłował bliźniego” - połączone jest $\mathrm{z}$ domaganiem się takiego samego miłowania, gdy tymczasem pierwsze pozbawione jest tej klauzuli. Jeśli Bóg miałby być Bogiem wzajemnego uznania kompetencji do definiowania dobra, („Oto człowiek stał się taki jak My, zna dobro i zło"), wówczas wystarczyłoby stosunki z nim określić formułą ,jak siebie samego” (i nie byłyby potrzebne aż dwa „najważniejsze przykazania"); uznaję prawo innego do definiowania dobra i od niego wymagam takiego uznania dla siebie. Tu jednak mojemu zobowiązaniu wobec Boga nie odpowiada żaden obowiązek po jego stronie, ani żadne moje prawo domagania się czegokolwiek (wiemy skądinąd, że od Boga religii, którego mamy obowiązek miłować bezwarunkowo, możemy oczekiwać tylko łaski - to typowe dla relacji między różnymi szczeblami hierarchii); moje zobowiązanie jest bezwarunkowe, jest więc $\mathrm{w}$ istocie, jako bezwarunkowe, zobowiązaniem do posłuszeństwa. Innymi

60 Mt 5, 44. Pozwala to rozszerzyć pojęcie „bliźni” na niektórych innych mężczyzn (odpowiednie przykazanie dekalogu, zakazujące pożądania kobiety, osła czy domu bliźniego, definiuje bliźniego jako mężczyznę z tego samego szczebla hierarchii, ale nie rozciąga się na kobiety, które zaleca się traktować nie gorzej niż osła, ale niekoniecznie lepiej).

${ }^{61}$ Mt 22, 37-39. 
słowy, „będziesz miłował bezwarunkowo” oznacza w gruncie rzeczy: będziesz posłuszny ${ }^{62}$. Zatem w porównaniu ze starotestamentową formuła pierwszego przykazania, odwołującą się expressis verbis do posłuszeństwa, mamy tu do czynienia wyłącznie ze zmianą językową: posłuszeństwo zostało tu nazwane miłowaniem. Nie sposób oprzeć się wrażeniu, że zmiana ta ma w gruncie rzeczy sens ideologiczny (dziś powiedziałoby się jeszcze - marketingowy): zasada miłowania ma z pewnością bardziej uniwersalny wymiar (a w każdym razie lepiej brzmi i tym samym lepiej się „sprzedaje”) niż zasada posłuszeństwa, dlatego jest ideologicznie bardziej funkcjonalne nazywanie posłuszeństwa miłością, niż ciągłe odwoływanie się do siły, jak w zakazie spożywanie owoców z drzewa wiadomości złego i dobrego czy grożeniu za nieposłuszeństwo pokaraniem zstępnych do trzeciego pokolenia (połączonym z łaskawą obietnicą wynagrodzenia za posłuszeństwo do pokolenia dziesiątego). Powstaje zatem pytanie, jak należy rozumieć połączenie zasady posłuszeństwa wobec wyższego (we wzorcu: wobec najwyższego) szczebla hierarchii z zasadą wzajemnie równego traktowania, jaką jest, wydobyta z archaicznej formy językowej, zasada „miłowania bliźniego jak siebie samego". Pierwsza z tych zasad ustanawia porządek hierarchiczny, gdzie $\mathrm{w}$ relacjach z podmiotami z innych szczebli obowiązuje panowanie i posłuszeństwo, więc wzajemne uznanie równych kompetencji do definiowania dobra (miłowanie jak siebie samego, uznanie równej kompetencji $\mathrm{w}$ definiowaniu dobra i stanowieniu prawa) może być co najwyżej rzadkim wyjątkiem od reguły. W ten sposób zarówno porządek kulturowy, jak i porządek polityczny łączą przeciwieństwa, ale w taki sposób, że jedno z nich (jedna z dwóch zasad) zachowuje swój status zasady podstawowej, drugie natomiast go traci ${ }^{63}$. Tym

62 Słynny Hymn o miłości (Kor 13) również jest apologią jednostronnego „miłowania" rezygnującego z jakichkolwiek wymagań czy choćby oczekiwań od obiektu miłości, odnosi się więc w istocie do miłości-posłuszeństwa a nie do miłości sensu stricto.

63 Odmiennym od religijnego, absolutyzującego posłuszeństwo i relatywizującego wzajemne uznanie równych statusów stron, sposobu łączenia wartości podstawowych, jest taki, który polega na zachowaniu absolutnego charakteru wzajemnego uznania równych statusów stron (równych kompetencji do definiowania dobra), na przykład w postaci zasady „równości wobec prawa”, i relatywizowaniu zasady posłuszeństwa i hierarchii (ograniczeniu jej działania do ściśle określonych i umownie ustalonych sytuacji). Zob. szerzej R. Paradowski, Problem normy absolutnej i dekalog społeczeństwa obywatelskiego, w: Instytucje państwa a społeczeństwo obywatelskie, red. A. Chodubski, L. Kacprzak, K. Pająk, Piła 2009, s. 26 i n. 
samym religia, wbrew swojej autodefinicji (jako religii miłości) okazuje się $\mathrm{w}$ istocie religią, albo powiedzmy wprost, ideologią posłuszeństwa.

Według Michela Onfray religia (autor ten ma zasadniczo na myśli tak zwane religie monoteistyczne) nie jest ufundowana na miłości, ale na nienawiści: „...do rozumu, któremu monoteiści przeciwstawiają posłuszeństwo i wypełnianie rozkazów; ...do życia [...jawna tanatofilia], do świata doczesnego, nieustannie deprecjonowanego na rzecz zaświatów pojmowanych jako jedyne źródło sensu, prawdy i błogostanu; ...do grzesznego ciała, [do] zmysłowości, [...] do kobiet i swobodnej seksualności" ${ }^{64}$.

Ale wróćmy do definicji religii ${ }^{65}$, a dokładniej - do związanej z nią kwestii transcendencji. Religia rzeczywiście jest związana $\mathrm{z}$ transcendencją, czyli wolnym aktem wyboru posłuszeństwa, dominacji i hierarchii, czyli „Bogiem” - jednym z dwóch „bogów” starotestamentowych opowieści o „stworzeniu człowieka”, podstawowych relacjach i wartościach podstawowych. Warto cały czas pamiętać, że Filozof Księgi Rodzaju ukazuje jednocześnie odmienną, niereligijną „opcję” - uznanie przeze mnie prawa każdego człowieka do definiowania dobra i domaga-

64 M. Onfray, Traktat..., op. cit., s. 76.

65 Definicję Tylora warto w związku z tym, co powiedziano wyżej, skorygować następująco: religia to wiara w duchowe byty, pojęte jako takie, którym ze strony człowieka należy się bezwarunkowe posłuszeństwo i rytualna (wobec tych bytów oraz ich rzeczywistej reprezentacji) demonstracja posłuszeństwa. Przy okazji, dla odróżnienia, definicja magii: to wiara w duchowe byty, które ze względu na swoją moc mają władzę nad człowiekiem, połączona z wiarą w to, że człowiek może okazjonalnie mieć nad nimi władzę za sprawą magicznego rytuału. Oto różnica: posłuszeństwo jest w religii wartością absolutną, natomiast w magii - względną, przy całej świadomości przewagi „duchowych bytów”; jest więc nie tyle posłuszeństwem w sensie ścisłym, co postawą ostrożności i czujności w obliczu tej przewagi. To jest również różnica między homo religiosus a „człowiekiem magii”: ten pierwszy definiuje siebie wobec wyższego szczebla hierarchii jako nic („Bóg jest wszystkim, człowiek jest niczym”), ten drugi - jako podmiot w obliczu silniejszego, ale nie „wszechmocnego”, podmiotu. Oprócz „człowieka religii” i „człowieka magii” warto wyróżnić jeszcze dwa ,uniwersalne” typy kulturowe człowieka: człowieka prawa (,przymierza”) i człowieka reklamy (homo shopping); pierwszego charakteryzuje uznanie równości praw swoich i cudzych, drugi bliższy jest człowiekowi religii. Podkreślam - dotyczy to typów, żaden człowiek nie jest absolutnym niczym (chociaż niektóre ideologie tak go „formatują”); każdy człowiek jest „mieszańcem kulturowym" - mieszaniną typów w różnych proporcjach, chociaż zawsze z dominującym udziałem któregoś z czterech typów. 
nie się takiego samego prawa dla siebie ${ }^{66}$. Bez tego, nawiasem mówiąc, nie jest możliwe żadne poważnie traktowane przymierze, nie jest możliwa umowa społeczna, nie jest możliwy porządek demokratyczny. Tak jak religia jest ideologią porządku autorytarnego (analiza biblijnych opowieści o antropogenezie pokazuje, że jest to jej jak najbardziej swoista funkcja, a nawet najgłębsza, transcendentna istota), tak samo alternatywna wobec religijnej, skądinąd również starotestamentowa, opcja wzajemnego uznania równych kompetencji do definiowania dobra jest ideologią - jedną z pierwszych ideologii porządku demokratycznego. Transcendencją jest zatem akt wyboru jednej spośród dwóch wartości podstawowych, z których jedną jest panowanie i posłuszeństwo, drugą natomiast wzajemne uznanie równych kompetencji do definiowania dobra. Tak więc religia rzeczywiście „łączy się" z transcendencją, „uczestniczy” w niej swoim par excellence ideologicznym wyborem autorytarnych wartości. I tak samo łączy się z transcendencją konfesyjne religioznawstwo.

\section{Religion as an ideology. The status of religious studies and the issue of transcendence}

\section{Summary}

The paper attempts to expand and transform the religious notion of transcendence, as well as the way in which religion is defined, which in Polish religious studies is dominated by a denominational approach, where the social functions of religion in particular (which according to academic religious studies determine the essential character of a religion) are considered 'non-specific,' while the 'specific' functions are those that the religion itself assumes to be such. The paper states that the essential character of religion goes beyond its social functions to encompass broadly understood ideological functions. This claim is illustrated by an analysis of the biblical story of the creation of the world and man, as this story demonstrates that religion is a product of the biblical axiological dilemma interpreted from an authoritarian viewpoint.

${ }^{66}$ Obie te „opcje” i związane z nimi akty (przede wszystkim akty wytwarzania samych tych opcji) składają się na całość (podwójnej, sprzecznej wewnętrznie) transcendencji, będącej skądinąd „przedmiotem” dialektycznej metafizyki. Przedmiot metafizyki, byt wyższy, ma formę dylematu. Zob. R. Paradowski, Afirmacja $i$ wiara a wybór metafizyczny. Bóg w strukturze absolutu, „Przegląd Religioznawczy" 2007, nr 4. 